
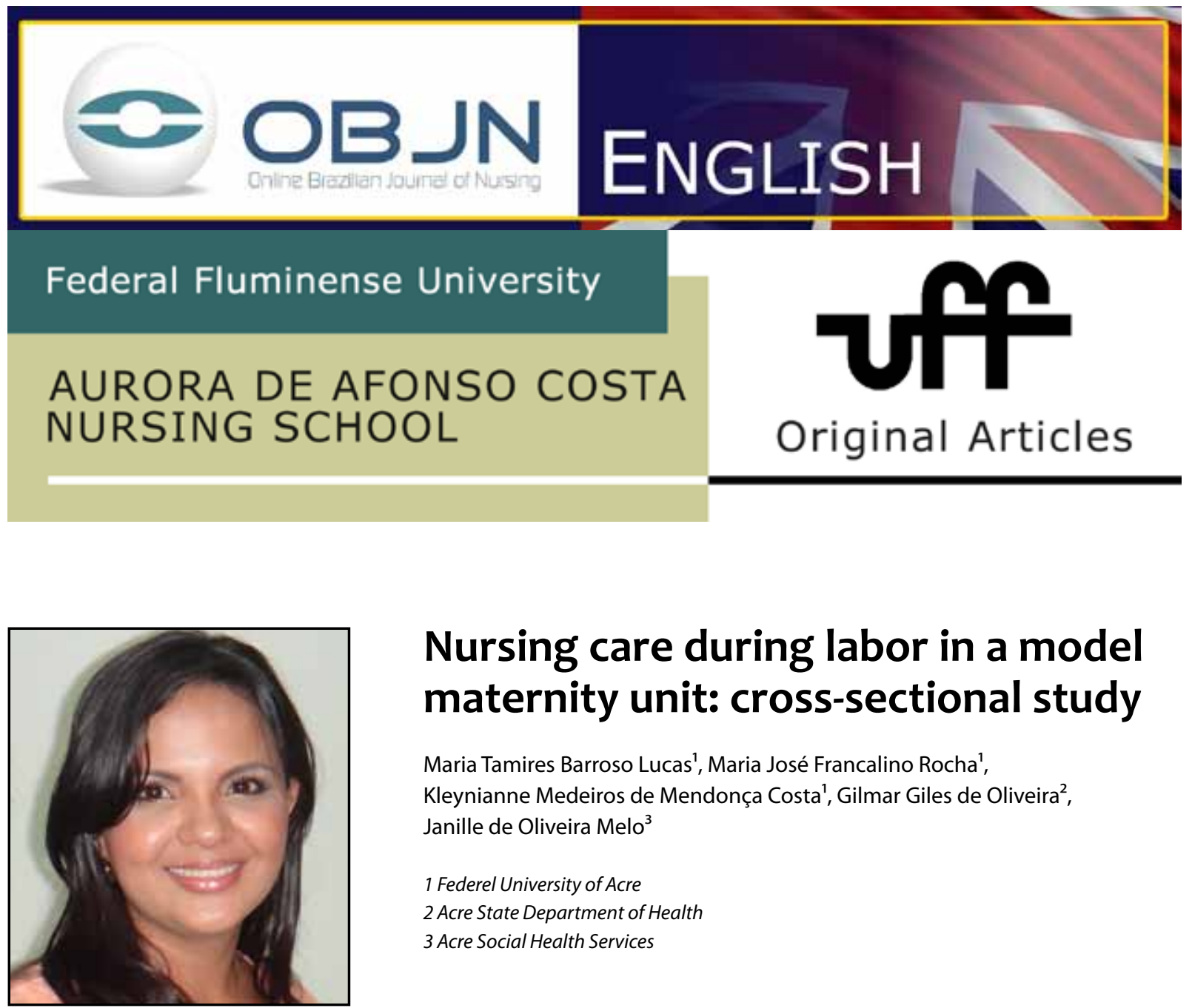

\title{
Nursing care during labor in a model maternity unit: cross-sectional study
}

\author{
Maria Tamires Barroso Lucas', Maria José Francalino Rocha', \\ Kleynianne Medeiros de Mendonça Costa', Gilmar Giles de Oliveira², \\ Janille de Oliveira Melo ${ }^{3}$ \\ 1 Federel University of Acre \\ 2 Acre State Department of Health \\ 3 Acre Social Health Services
}

\begin{abstract}
Aim: To evaluate nursing care measures offered to women in labor before delivery in the model maternity unit of Vale do Jurua region/AC, according to the dictates of care quality indicators proposed by the Ministry of Health. Method: Cross-sectional study, descriptive and quantitative approach, participant observation method. Results: There were no restrictions on fluids, or permanence of a companion; non-pharmacological methods were stimulated; the absence of the use of the partograph was noteworthy (A); enemas, intestinal cleansers and shaving were eliminated from the routine procedures (B); some pain relief technologies without sufficient evidence for their indication were not used (C); frequent vaginal examination, cardiotocography and oxytocics administration occurred in more than $30 \%$ of cases, according to each conduct. Conclusion: excellence in care provision in delivery requires reflection of the parts involved, as well as implementation and consolidation of existing public policies to ensure comprehensive and humane care measures.
\end{abstract}

Descriptors: Humanizing Delivery; Nursing Care; Labor, Obstetric. 


\section{INTRODUCTION}

The delivery process is a special phase in women's and their partners' universe. It is a moment full of different and ambivalent meanings that need to be interpreted and understood, because the episodes experienced by women may reflect positively or negatively at this moment ${ }^{(1)}$.

During labor, the women need care actions free of trauma. The humanized practice collaborates so that it proceeds as smoothly as possible. The nurses are essential in this process because they act on the hosting and advocate favoring non-invasive care ${ }^{(2)}$.

Obstetric nursing has many challenges and the minimization of maternal suffering is among them. Studies are conducted to highlight the best actions, but even in the face of scientific evidence, it is still common to have practices that should have been eliminated ${ }^{(3)}$.

Some labor and childbirth evidence-based habits have been widely reported in various social spheres. However, few institutions have respected the implementation of such guidelines, resisting what is considered safe and beneficial in the process of giving birth nowadays ${ }^{(4)}$.

The professionals who provide care to laboring women must be prepared to meet the mother respecting all the concepts and meanings that exist at this time because the birth experience is different for each patient and will depend on the experiences they had during pregnancy and the idealizations they have for the time of birth ${ }^{(5)}$.

In view of these considerations, this study aimed to characterize the nursing care provided to women during labor before delivery, especially in the context of the guidelines recommended by the World Health Organization (WHO) ${ }^{(6)}$ and Ministry of Health $(\mathrm{MOH})^{(7)}$, highlighting the procedures and care provided by professionals in the first clinical stage of labor.
The importance of this research was to acknowledge the assistance provided by the nursing team during labor, focusing on the healthcare quality indicators proposed by the $\mathrm{WHO}^{(6)}$ and $\mathrm{MOH}^{(7)}$.

\section{METHODS}

A cross-sectional descriptive study with a quantitative approach through participant observation method, carried out from October 2013 to February 2014 in a reference hospital in the city of Cruzeiro do Sul, Acre.

In the city under study there is only one public system accredited hospital that provides care for women during childbirth. This institution assists pregnant, laboring and postpartum women and patients with gynecological pathologies, of the city itself and neighboring municipalities that do not have health services specialized in the treatment of women.

The study population consisted of 23 members of a nursing team working in the assistance to women during the first clinical stage of labor, working in shifts of 12 per 60 and 12 per 36 hours, making a total workload of 10 or 14 shifts a month.

For a description of the practices used in the labor care practices in the maternity ward under study, the following distribution tables of variables were structured according to the categorization of the $\mathrm{WHO}^{(6)}$ :

Category A: supply of liquid; preservation of the privacy of the woman in labor; permission of presence of the companion; auscultation of fetal heartbeats; use of aseptic technique during vaginal examination; encouragement to the change of position according to the free will of the woman in labor; use of the partograph; provision of information and explanations according to the interest of the laboring woman; en- 
couragement in walking; advice to keep upright posture; help on use of a rocking ("horse") birth chair; encouragement to exercise on birthing ball; keeping environment cozy and free of noise; decreasing the illumination; teaching of breathing and relaxation techniques; maintaining ambient temperature; use of physical touch.

Category B: Routine enema; routine shaving; routine intravenous infusion. Category C: contact with water (hydrotherapy); transcutaneous electrical stimulation therapy; soothing aromas; cryotherapy (compresses); chromotherapy; homeopathy; floral and acupuncture therapy. Category D: supply of solid food; cardiotocography; frequent vaginal contact examination; oxytocin.

The instrument for data collection consisted of a questionnaire prepared by the researchers with closed and open questions, and its construction used directives from the Practical Guide of Assistance to Vaginal Childbirth ${ }^{(6)}$ and from the Birth, Abortion and Postpartum Manual - Humanized Care to Women ${ }^{(5)}$.

The data collection instrument has been implemented for three shifts of six hours during periods of morning, afternoon and evening respectively in order to improve its efficacy. It was possible to observe 18 hours of care actions provided to women in labor. In this phase we could notice the difficulty of filling it in, questions misinterpreted, and the need for introduction or bypassing questions.

Data collection occurred from October 2013 to February 2014. It was intended to observe the actions taken by the nursing staff in assisting pregnant women during the first clinical period of labor. The interest was not the personal performance of any individual or professional, but to check if the procedures recommended by $\mathrm{MOH}$ and $\mathrm{WHO}$ were being adopted in providing care to women giving birth. To avoid any information bias due to the change of behavior in the provision of care to the patients, respondents did not have access to the instrument. It is relevant to note that two of the researchers were part of the area studied as they had been working in the pre-labor department. It was decided that the researchers themselves would apply the Observation Script, when they were not working in the assistance, for they knew the researched sector and had free access to the area, and so they would not draw the attention of the students and hinder the change in behavior during the provision of care to the mother.

The observations were made by researchers seeking to obtain a representative sample of the studied reality, with monitoring of six-hour shifts, seven in the morning, eight in the afternoon and twenty-two at night: a total of 37 shifts, totaling 222 hours of observation. Thus, it was possible to observe all the nursing staff who provided care to women.

To enable the collection of data, we requested the collaboration and authorization of the managers of the hospital unit. Upon completion of data collection, we requested that the professional nursing staff who worked in the monitoring of the pre-birth to sign the authorization form for the use of the collected data.

The ethical aspects were based on the norms of the National Health Council, in its resolution $466^{(7)}$.

The research project was submitted to the Research Ethics Committee (REC) of the Federal University of Acre under the protocol 23107.015776/2011-01 and approved on December 14, 2011.

\section{RESULTS}

Procedures and practices developed by the nurses in the unit under study are shown in Table 1 , grouped according to the degree of recom- 
mendation from WHO. It was found that supply of liquids was a common practice in $59.5 \%$ of cases; mothers' privacy was preserved (97.6\%), there were no restrictions on the presence of a companion, fetal heartbeats were checked in $100 \%$ of pregnant women; during the vaginal touch examination practice the use of aseptic technique was prevalent $(92.9 \%)$, the change in position according to the free choice of the woman in labor was oriented (47.6\%) and the partograph was used in only $2.4 \%$ of cases.

All the patients were stimulated at any time to make use of at least one non-pharmacological method of pain relief, as ambulation (92.9\%); use of vertical positions (83.3\%), to exercise in the rocking birthing chair ("horse") (81.0\%) and, to a lesser extent, the birthing ball (16.7\%). Some comfort measures (such as keeping a cozy and noise-free environment, stimulating breathing and relaxation techniques, keeping room temperature and employing physical touch) were also observed, but the percentage of each of these behaviors was less than $35 \%$, and so they can not be considered common and collective practices.

Concerning the harmful conduct and / or practices to be eliminated - Category "B" (Table 2) shows that the enema (97.6\%), shaving (100.0\%) and venous access along with fluid infusion (92.9\%) were not used routinely in the studied unit. Amongst the behaviors of the category " $\mathrm{C}$ " the use of non-pharmacological methods of pain relief with no sufficient evidence to indications were observed. It was found that hydrotherapy was used in $21.4 \%$ of the events, especially the shower. Actions such as the use of compresses (cryotherapy), chromotherapy, technical use of Transcutaneous Electrical Stimulation (TSE), of soothing aromas, floral, acupuncture and homeopathic therapies were not seen in the institution. As for category " $D$ " that highlights some behaviors that are often used improperly, we observed that solid foods were offered (54.8\%); the patients were subjected to the procedure of cardiotocography (33.3\%) and there were no records of frequent vaginal rings. Regarding the use and increase of oxytocics, this was a more common practice, and was administered in $35.7 \%$ of women in labor.

Table 1 - Distribution of the procedures performed in nursing care in the first clinical stage of labor according to $\mathrm{WHO}$ and $\mathrm{MOH}$ category "A" of delivery assistance. Acre, 2013-2014.

\begin{tabular}{|c|c|c|c|c|c|}
\hline \multirow{2}{*}{$\begin{array}{l}\text { Cate- } \\
\text { gory }\end{array}$} & \multirow{2}{*}{ Procedures $(\mathrm{N}=42)$} & \multicolumn{2}{|c|}{ Yes } & \multicolumn{2}{|c|}{ No } \\
\hline & & $\mathbf{N}$ & $\%$ & $\mathbf{N}$ & $\%$ \\
\hline \multirow{17}{*}{$A^{*}$} & Supply of liquids & 25 & 59,5 & 17 & 40,5 \\
\hline & $\begin{array}{l}\text { Preservation of the } \\
\text { privacy of the woman } \\
\text { in labor }\end{array}$ & 41 & 97,6 & 1 & 2,4 \\
\hline & $\begin{array}{l}\text { Permission of presen- } \\
\text { ce of the companion }\end{array}$ & 41 & 97,6 & 1 & 2,4 \\
\hline & $\begin{array}{l}\text { Auscultation of fetal } \\
\text { heartbeats }\end{array}$ & 42 & 100 & - & - \\
\hline & $\begin{array}{l}\text { Use of aseptic tech- } \\
\text { nique during vaginal } \\
\text { examination }\end{array}$ & 39 & 92,9 & 3 & 7,1 \\
\hline & $\begin{array}{l}\text { Encouragement to the } \\
\text { change of position }\end{array}$ & 20 & 47,6 & 22 & 52,4 \\
\hline & Use of the partograph & 1 & 2,4 & 41 & 97,6 \\
\hline & $\begin{array}{l}\text { Provision of informa- } \\
\text { tion and explanations } \\
\text { according to interest } \\
\text { of laboring woman }\end{array}$ & 4 & 9.5 & 38 & 90,5 \\
\hline & Encourage walking & 39 & 92,9 & 3 & 7,1 \\
\hline & $\begin{array}{l}\text { Advice to keep upri- } \\
\text { ght posture }\end{array}$ & 35 & 83,3 & 7 & 16,7 \\
\hline & $\begin{array}{l}\text { Help on using of } \\
\text { rocking ("horse") birth } \\
\text { chair }\end{array}$ & 34 & 81 & 8 & 19 \\
\hline & $\begin{array}{l}\text { Encouragement to } \\
\text { exercises on birthing } \\
\text { ball }\end{array}$ & 7 & 16,7 & 35 & 83,3 \\
\hline & $\begin{array}{l}\text { Ambient cozy and free } \\
\text { of noise }\end{array}$ & 14 & 33.3 & 28 & 66,7 \\
\hline & Dimming lights & 13 & 30,9 & 29 & 69,1 \\
\hline & $\begin{array}{l}\text { Teaching of breathing } \\
\text { and relaxation tech- } \\
\text { niques }\end{array}$ & 14 & 33,3 & 28 & 66,7 \\
\hline & $\begin{array}{l}\text { Maintaining ambient } \\
\text { temperature }\end{array}$ & 14 & 33.3 & 28 & 66,7 \\
\hline & Use of physical touch & 6 & 14,3 & 36 & 85,7 \\
\hline
\end{tabular}

Source: Authors' Elaboration, 2014.

Nota: *Procedures clearly useful that should be encouraged. 
Table 2 - Distribution of the procedures performed in nursing care in the first clinical stage of labor according to WHO and $\mathrm{MOH}$ categories " $B$ ", " $C$ " and " $D$ " of delivery assistance. Acre, 2013-2014.

\begin{tabular}{|c|c|c|c|c|c|}
\hline \multirow{2}{*}{$\begin{array}{l}\text { Cate- } \\
\text { gory }\end{array}$} & \multirow{2}{*}{ Procedures $(\mathrm{N}=42)$} & \multicolumn{2}{|c|}{ Yes } & \multicolumn{2}{|c|}{ No } \\
\hline & & $\mathbf{N}$ & $\%$ & $\mathbf{N}$ & $\%$ \\
\hline \multirow{3}{*}{$\mathrm{B}^{* *}$} & Routine enema & 1 & 2,4 & 41 & 97,6 \\
\hline & Routine Shaving & - & - & 42 & 100 \\
\hline & $\begin{array}{l}\text { Routine intravenous } \\
\text { infusion }\end{array}$ & 3 & 7,1 & 39 & 92,9 \\
\hline \multirow{10}{*}{$C^{* * *}$} & $\begin{array}{l}\text { Contact with water } \\
\text { (hydrotherapy) }\end{array}$ & 9 & 21,4 & 33 & 78,6 \\
\hline & Transcutaneous & & & & \\
\hline & Electrical Stimulation & - & - & 42 & 100 \\
\hline & Therapy (EST) & & & & \\
\hline & Soothing Scents & - & - & 42 & 100 \\
\hline & $\begin{array}{l}\text { Cryotherapy (com- } \\
\text { presses) }\end{array}$ & - & - & 42 & 100 \\
\hline & Color therapy & - & - & 42 & 100 \\
\hline & Homeopathy & - & - & 42 & 100 \\
\hline & Floral therapy & - & - & 42 & 100 \\
\hline & $\begin{array}{l}\text { Acupuncture tech- } \\
\text { niques }\end{array}$ & - & - & 42 & 100 \\
\hline \multirow{4}{*}{$D^{* * * *}$} & Offer of Solid Food & 23 & 54,8 & 19 & 45,2 \\
\hline & Cardiotocography & 14 & 33,3 & 28 & 66,7 \\
\hline & $\begin{array}{l}\text { Frequent vaginal } \\
\text { touch examination }\end{array}$ & - & - & 42 & 100 \\
\hline & Oxytocin & 15 & 35,7 & 27 & 64,3 \\
\hline
\end{tabular}

Source: Authors' elaboration, 2014.

Nota: **Clearly harmful or ineffective practices that should be eliminated. ${ }^{* * *}$ Practices without sufficient evidence to foster a recommendation that should be used with caution while further research do not make them evident. ${ }^{* * * *}$ Practicesoften used improperly.

\section{DISCUSSION}

With regard to the relevant conduct that should be encouraged $(A)$, there were no fluids restrictions in the maternity ward under study. Although there is no limitation, no liquid was offered to about $40 \%$ of the pregnant women, a percentage considered high and in conflict to what is recommended. The offer of oral flui$\mathrm{ds}$ is part of the indications of the $\mathrm{WHO}^{(6)}$ and $\mathrm{MOH}^{(7)}$ during the whole process of parturition and is characterized as humanized midwifery practice and should be encouraged by the nursing staff.

In meta-analysis, the authors conclude that there is no justification for restriction of liquids in cases of low risk of cesarean sections and use of general anesthesia, so the offer should be encouraged $^{(8)}$.

This research showed that the choice of companion is up to the woman in labor. The practice is part of the hospital routine during the delivery process. The percentages were higher than those found in Santa Catarina (RS), where only $54.8 \%$ of public health institutions allowed the partner's regular presence ${ }^{(9)}$.

In studies, several authors propose that the support must be placed in the context of pregnancy since the prenatal stage so they can achieve the necessary knowledge for good assistance to the needs of women during labor and delivery ${ }^{(10)}$.

The presence of a partner contributes to reduction of cesarean deliveries and more vaginal deliveries, and decreased analgesia, labor duration, infants with low Apgar and negative birth idealization $^{(11)}$.

The verification of fetal heartbeats is common among professionals in the studied institution and was offered to all the women in labor. In some cases, however, the intervals were longer than one hour. There is not sufficient evidence to establish a frequency considered optimal for such monitoring, but a review study indicates that auscultation should be conducted intermittently, recommending a 15 to 30 -minute interval to monitor a low risk labor ${ }^{(3)}$.

The vaginal examination followed the established standards.

We observed the lack of use of the partograph by the staff of the studied institution. The low frequency in the use of this tool was also observed in other studies ${ }^{(3,12)}$. It is noteworthy that the use of the partogram in maternity war- 
ds has been mandatory by WHO regulations ${ }^{(13)}$ since 1994.

The professional support and supply of information according to the interest of the laboring woman was not a frequent practice. One of the main factors of satisfaction with the service is related to the guidelines on the procedures performed $^{(14)}$.

It was observed that most of the professionals stimulated ambulation during labor and, less frequently, the use of other methods of comfort and pain relief.

The change of position should be encouraged for women during childbirth. The walking and the vertical position in the first stage of labor are recommended ${ }^{(15)}$. With respect to "horse" rocking chair exercises, there are few studies which refer to this technique, and there is not enough scientific evidence for discussion.

In only $16.7 \%$ of cases we observed the stimulus to exercise with a birthing ball. These data contrast with another study in which all women have made use of the technique. The ball can be used as a recreational tool, allowing the distraction of laboring women who, relaxed, become less anxious ${ }^{(16)}$.

During the observations, it was revealed that physical touch was a practice offered by companions and little supplied by professionals. This fact corroborates another study of literature systematic review in which the authors describe the frequent involvement of the companion in training and doing massage during labor ${ }^{(17)}$.

As for the breathing techniques, the study showed that these had little encouragement (33.3\%). These data are contrary to WHO and $\mathrm{MOH}$ indications. In addition to reducing the sensation of pain, studies show that breathing exercises can improve maternal blood saturation and hence the fetal circulation, reducing anxiety and providing relaxation for pregnant women in labor ${ }^{(18)}$.
About the attention to room temperature, offering a calm environment, free from noise and excessive light, it was observed that these practices are not common in care for women during childbirth.

In pre-delivery environments, in general, the notions of comfort such as lighting, noise reduction and privacy are not taken into account ${ }^{(4)}$.

Of the practices categorized as clearly harmful or ineffective behavior that should be eliminated (B), shaving, intestinal cleansers and routine venous access with liquid infusion are practices that were abolished in the institution under study. Evidence shows that these habits increase the cost of care, bring discomfort to the patient and show no differences in infection rates $^{(3,19)}$.

Regarding the non-pharmacological therapies for pain relief that do not have enough evidence for his statement, only the spray bath with warm water was offered to $21.4 \%$ of pregnant women. Cryotherapy, color therapy, the use of Transcutaneous Electrical Stimulation (TSE), soothing scent, floral, acupuncture and homeopathic therapies were not provided to women.

Hydrotherapy has been strongly encouraged in obstetric care. An investigation showed that it is quite safe, improves the well-being of pregnant women and increases the feeling of relaxation. Other studies point to pain reduction in women exposed to cryotherapy ${ }^{(18)}$.

As for aromatherapy, a systematic review has shown that the technique has greater influence on nulliparous patients and reduces pain only in that group, although the reduction of anxiety was observed regardless of parity ${ }^{(17)}$.

Electronic fetal monitoring, usually performed by cardiotocography - although not common in the unit under study, was observed in over $30 \%$ of cases observed. Some studies report that cardiography has disadvantages, since it is associated with increased cesarean rates and 
obstetric and instrumental interventions even in vaginal deliveries; it also hinders mothers' locomotion, is difficult to read thus making room for false-positives, and should therefore only be indicated in pregnancies with risk of prenatal death. So, as a common procedure, this practice should be discouraged ${ }^{(3)}$.

As for vaginal touch examination, no contradictions were identified with what is advised, since the recommendation is that a touch examination should be performed in a two-hour interval. In this study, most of the pregnant women received only one examination on the observed range, but failures in orientation were observed, because few professionals explained the indication of the practice. Opposite data were found in other studies, showing the conduction of examination on intervals of less than one hour ${ }^{(12)}$.

Regarding the use of oxytocin, the results were similar to other studies, occurring in around 30.0 to $36.0 \%$ of cases $^{(12,13)}$.

According to the $\mathrm{WHO}^{(6)}$ the administration of oxytocics at any time before delivery should be avoided, since their effect might not be properly controlled.

With respect to care quality indicators offered by the nursing staff, the team under study applied the available scientific evidence, and several behaviors and appropriate technologies were used often in the provision of care to women during childbirth.

\section{CONCLUSION}

The results of this study allowed us to evaluate the nursing care, through quality indicators proposed by the $\mathrm{WHO}$ and $\mathrm{MOH}$, offered to laboring women in the institution studied. It was possible to analyze the behaviors and interventions performed by the nursing staff with the laboring mother.
We concluded that the study hospital staff adopts the measures recommended by WHO and $\mathrm{MOH}$ for a humanized birth; requiring constant evaluations aimed at improving care quality indicators.

However, deficiencies in the care process regarding the provision or lack of certain behaviors / practices considered essential and easy to deploy, as the absence of labor monitoring through the partograph and supply of essential guidelines for pregnant women, were identified.

Even with the support of some public policies that deal in providing a quality obstetric care, we could identify practices that still did not fit the best evidence.

Thus, changes are still necessary, especially regarding the change in the behaviors of professionals who provide assistance, as they have the important role of enforcing the development of recommended practices, ensuring a safe, comprehensive and quality service.

We could see that some deficiencies found in this study can be mitigated with the development of permanent learning strategies to be conducted with teams in order to strengthen the humanized care practice in the obstetric ward.

To achieve a level of excellence in labor assistance in the studied institution, a reflection on the part of the staff involved, with effective participation of the managers, is recommended to organize the work process and to qualify professionals working in the area for achieving the best scientific evidence and the development of skills related to the delivery of humanized care. The implementation and consolidation of existing public policies is required to ensure the completeness of quality health production. 


\section{REFERENCES}

1. Oliveira LR. Diagnóstico e intervenções de enfermagem durante o trabalho de parto. In: Carvalho GM, Lula HM, Oliveira LR, organizadores. Diagnóstico e intervenções de enfermagem em ginecologia, obstetrícia e neonatologia. São Caetano do Sul:Yendis; 2010.

2. Santos GS, Souza JLO, Almeida LS, Gusmão MH. A importância do enfermeiro no atendimento humanizado no pré-parto. Diálogos Ciênc. 2012 [cited 2013 nov 10];10(31):224-8. Available from: http://dialogos.ftc.br/index.php?option=com_co ntent\&task=view\&id $=328 \& \mid$ temid $=1$

3. Porto AMF, Amorim MMR, Souza ASR. Assistência ao primeiro período do trabalho de parto baseada em evidências: [revisão]. Femina. 2010;38(10)527-37. Cited: 15 Fev. 2013. Available from: http://bhpelopartonormal.pbh.gov.br/ estudos_cientificos/arquivos/artigo_femina_assistencia_ao_parto_parte_I.pdf

4. Pasche DF, Vilela MEA, Martins CP. Humanização da atenção ao parto e nascimento no Brasil: pressupostos para uma nova ética na gestão e no cuidado. Tempus Actas Saúde Col [internet]. 2010 [cited 15 nov 2013];4(4):105-17. Available from: http://www.tempusactas.unb.br/index. php/tempus/article/view/838/801

5. Ministério da Saúde. Secretaria de Políticas de Saúde. Área Técnica de Saúde da Mulher. Parto, aborto e puerpério: assistência humanizada à mulher. Brasília: Ministério da Saúde; 2001.

6. Organização Mundial da Saúde. Assistência ao parto normal: um guia prático. Genebra: Organização Mundial da Saúde; 1996.

7. Ministério da Saúde. Conselho Nacional de Saúde. Resolução 466, de 12 de dezembro de 2012. Dispõe sobre diretrizes e normas regulamentadoras de pesquisas envolvendo seres humanos. Diário Oficial da União. 13 jun 2013 [cited: 2013 nov 10];1: 59. Available from: http://conselho. saude.gov.br/resolucoes/2012/Reso466.pdf

8. Singata M, Tranmer J, Gyte GML. Restricting oral fluid and food intake during labour. Cochrane Database Syst Rev. 2010;(1):CD003930.

9. Bruggemann OM, Oliveira ME, Martins HEL, Alves MC, Gayeski E. A inserção do acompanhante de parto nos serviços públicos de saúde de Santa Catarina, Brasil. Esc Anna Nery. 2013 [cited 2014 Jan 26];17(3):432-8. Available from: http:// www.scielo.br/pdf/ean/v17n3/1414-8145ean-17-03-0432.pdf

10. Frutuoso LD, Bruggemann OM. Parturient women's companions knowledge of Law 11.108/2005 and their experience with the woman in the obstetric center. Texto Contexto - enferm [internet]. 2013 [cited 2013 Nov 3];22(4):909-17. Available from: http://www.scielo.br/pdf/tce/ v22n4/06.pdf

11. Hodnett ED, Gates S, Hofmeyr GJ, Sakala C. Continuous support for women during childbirth. Cochrane Database Syst Rev. 2011;(2):CD003766.

12. Giglio MR, Franca E, Lamounier JA. Avaliação da qualidade da assistência ao parto normal. Rev Bras Ginecol Obstet. 2011;33(10):297-304.

13. Silva FMB, Paixao TCR, Oliveira SMJV, Leite JS, Riesco MLG, Osava RH. Care in a birth center according to the recommendations of the World Health Organization. Rev Esc Enferm USP. 2013;47(5):1031-8.

14. Müller J, Collaço VS, Santos EKA. O significado para as puérperas do suporte profissional no processo parturitivo. Rev Cient CENSUPEG. 2013 [cited 2013 apr 7];(2):78-88. Available from: http://revistacientifica.censupeg.com.br/ojs/ index.php/RevistaCientificaCENSUPEG/article/ view/117

15. Oliveira AS, Damasceno AKC, Moraes JL, Moreira KAP, Teles LMR, Gomes LFS. Technology used by companions in labor and childbirth: a descriptive study. Online Braz J Nurs [internet]. 2014[cited 2013 nov 15];13(1):36-45. Available from: http:// www.objnursing.uff.br/index.php/nursing/article/view/4254

16. Silva LM, Oliveira SMJV, Silva FMB, Alvarenga MB. Using the Swiss ball in labor. Acta Paul Enferm [internet]. 2011[cited 2014 Apr 10];24(5):656-62. Available from: http://www.scielo.br/pdf/ape/ v24n5/en_10v24n5.pdf

17. Gayeski $M E$, Brüggemann, $O M$. Métodos não farmacológicos para alívio da dor no trabalho de parto: uma revisão sistemática. Texto Contexto -Enferm. 2010 [cited 3 mar 2014];19(4):774-82. Available from: http://www.scielo.br/pdf/tce/ v19n4/22.pdf 
18. Silva DAO, Ramos MG, Jordão VRV , Silva RAR, Carvalho JBL, Costa MMN. Use of non-pharmacological methods for providing pain relief during the natural childbirth: integrative review. J Nurs. UFPE on line. 2013 [cited 2013 Nov 15];7(5):416170. Available from: http://www.revista.ufpe.br/ revistaenfermagem/index.php/revista/article/ view/2582

19. Carvalho VF, Kerber NPC, Busanello J, Gonçalves BG, Rodrigues EF, Azambuja EP. How the workers of a birthing center justify using harmful practices in natural childbirth. Rev Esc Enferm USP. 2012;46(1):29-35.
All authors participated in the phases of this publication in one or more of the following steps, in According to the recommendations of the International Committee of Medical Journal Editors (ICMJE, 2013): (a) substantial involvement in the planning or preparation of the manuscript or in the collection, analysis or interpretation of data; (b) preparation of the manuscript or conducting critical revision of intellectual content; (c) approval of the versión submitted of this manuscript. All authors declare for the appropriate purposes that the responsibilities related to all aspects of the manuscript submitted to OBJN are yours. They ensure that issues related to the accuracy or integrity of any part of the article were properly investigated and resolved. Therefore, they exempt the OBJN of any participation whatsoever in any imbroglios concerning the content under consideration. All authors declare that they have no conflict of interest of financial or personal nature concerning this manuscript which may influence the writing and/or interpretation of the findings. This statement has been digitally signed by all authors as recommended by the ICMJE, whose model is available in http://www. objnursing.uff.br/normas/DUDE_eng_13-06-2013.pdf

Received: 09/24/2014

Revised: $12 / 23 / 2014$

Approved: $12 / 23 / 2014$ 